\title{
TEKNOLOGI TEPAT GUNA PEMANFAATAN SERBUK GERGAJI DAN PUPUK TINJA SEBAGAI CAMPURAN MEDIA TUMBUH BIBIT HUTAN TANAMAN RAKYAT
}

\section{APPROPRIATE TECHNOLOGY: THE USE OF SAWDUST AND HUMANURE AS A GROWING MEDIA MIXTURE FOR PLANTS FOREST SEEDLING OF COMMUNITY}

\author{
Oleh: \\ Deselina, Efratenta KD, dan Bilman WS \\ Email:deselina@ymail.com,efra_tenta@yahoo.com, \\ bilmanwilmansimanihuruk@yahoo.co.id \\ Jurusan Kehutanan Fakultas Pertanian UNIB \\ Jurusan Budidaya Pertanian Fakultas Pertanian UNIB
}

\begin{abstract}
The purpose of this community service activity is to produce qualified seeds of forest plants, reduce sawdust waste and human sewage, providing value-added sawdust and human sewage so that it becomes more useful, reducing the use of topsoil, thereby reducing topsoil dredging. This service activity was conducted in August to October 2014 at Pulau Beringin Village, District of Pondok Kelapa, Central Bengkulu. The targets of the activity are the members of farmers and members of the youth group. The activity uses methods of counseling, training and demonstration. Making the mixture media from sawdust and humanure for growing media of community plantation forest seedling in Pulau Beringin Village is one right step in the process of sawmill waste business and household waste. Making the growing medium mixture of these wastes in addition to add to the skills of the members of farmer groups and the youth institution in managing waste can also be used as an attempt to increase the income of members of farmers and members of the youth group in the village of Pulau Beringin.
\end{abstract}

Keywords: sawdust, humanure, community plantation forest seedlings, Pulau Beringin

\section{PENDAHULUAN}

Masalah utama yang dihadapi dalam bidang kehutanan di Indonesia adalah kerusakan hutan yang sangat intensif. Kerusakan setiap tahun mencapai luas antara 900.000 - 600.000 Ha. Kerusakan ini terutama disebabkan oleh kegiatan pembalakan atau eksploitasi, peladangan berpindah, perluasan lahan transmigrasi dan kebakaran hutan.

Provinsi Bengkulu dengan luas wilayah 1.978.870 hektar termasuk salah satu wilayah yang kondisi lahan kritisnya cenderung meningkat dari waktu ke waktu. Provinsi Bengkulu mempunyai lahan kritis di dalam dan di luar kawasan hutan. Pada tahun 1998/1999 luas lahan kritis di dalam dan luar kawasan adalah 78.724 Ha dan 499.824 Ha (Sub Balai RLKT, 1999). Semenara itu berdasarkan hasil inventarisasi lahan kritis pada lahan kawasan budidaya pertanian di Provinsi Bengkulu terdapat 1.045.359 hektar lahan kritis yang terbagi atas sangat kritis 160.563 hektar, kritis 339.256 hektar, agak kritis 
286.319 hektar dan potensial kritis 259.221 hektar (Departemen Kehutanan dan Perkebunan, 2000).

Deforestasi dan degradasi lahan tidak boleh dibiarkan terus berlanjut. Keberadaan lahan kritis pun tidak dapat dibiarkan begitu saja. Untuk itu perlu dilakukan upaya merehabilitasi lahan kritis tersebut sehingga dapat memberi manfaat sebesar-besarnya untuk kesejahteraan rakyat Menurut Undang-undang Nomor 41 tahun 1999 tentang Kehutanan, rehabilitasi hutan dan lahan (HL) adalah upaya memulihkan, mempertahankan dan meningkatkan fungsi hutan dan lahan sehingga daya dukung, produktivitas peranannya dalam mendukung sistem penyangga kehidupan tetap terjaga.

Menyadari kenyataan bahwa kerusakan hutan Indonesia sudah cukup besar maka upaya pemulihan kawasan hutan dan rehabilitasi lahan kritis merupakan tanggung jawab kita sebagai masyarakat Indonesia. Oleh karena itu diperlukan upaya serius, terencana dan berkelanjutan untuk mengatasi hal tersebut yang melibatkan semua pihak terkait (stakeholders) yakni pemerintah, masyarakat dan dunia usaha.

Beberapa kegiatan rehabilitasi hutan dan lahan yang sedang dilaksanakan Departemen Kehutanan antara lain Gerakan Nasional Rehabilitasi Hutan dan Lahan (Gerhan) seluas 3 (tiga) juta hektar selama 5 tahun, kegiatan Kecil Menanam Dewasa Memanen (KMDM) untuk mempercepat dan memperluas target Gerhan, Pengembangan Hutan Rakyat seluas 2 (dua) juta hektar dan Percepatan Pembangunan Hutan Tanaman Industri (HTI) termasuk HTI-Rakyat seluas 5 (lima) juta hektar (BP DAS Ketahun, 2007). Jenis tanaman kayu-kayuan yang umumnya dikembangkan pada kegiatan hutan rakyat oleh sebagian besar masyarakat di Bengkulu dikelompokkan menjadi 14 jenis yaitu Bambang Lanang, Bayur, Gmelina, Jati, Kayu Afrika, Kayu Bawang, Kayu Gadis, Mahoni, Medang, Meranti, Merambung, Mindi, Sengon dan Surian. Dari berbagai jenis tersebut, beberapa tanaman yang menjadi komoditi unggulan adalah Meranti, Kayu Bawang dan Kayu Afrika. Jenis-jenis unggulan tersebut disamping mempunyai nilai ekonomis yang tinggi juga tingkat kesesuaian tumbuhnya baik di wilayah Bengkulu.

Salah satu faktor yang sangat mendukung keberhasilan kegiatan rehabilitasi hutan dan lahan di atas yaitu tersedianya bibit tanaman kehutanan yang bermutu baik dan jumlahnya mencukupi untuk ditanami. Permasalahan yang dihadapi adalah dalam mempersiapkan bibit yang bermutu dalam jumlah banyak karena pada saat evaluasi Gerhan ternyata banyak bibit yang ditolak karena tidak sesuai kriteria kualitas bibit. Menanam bibit dengan kualitas yang kurang baik merupakan salah satu penyebab kurang berhasilnya kegiatan rehabilitasi hutan dan lahan.

Untuk mendapatkan bibit yang bermutu salah satu faktor yang harus diperhatikan adalah media tanam. Untuk memenuhi kebutuhan bibit untuk kegiatan di atas tentu dibutuhkan media tanam yang cukup banyak. Kesuburan tanah merupakan salah satu faktor yang besar pengaruhnya terhadap pertumbuhan tanaman selama di persemaian. Pada tanah persemaian yang miskin hara pertumbuhan tidak menguntungkan apabila kelak ditanam di lapangan maka daya hidup dan pertumbuhan selanjutnya kurang baik. 
Media tanam yang biasa digunakan untuk pertumbuhan bibit adalah tanah lapisan atas (topsoil) karena lapisan ini kandungan bahan organik dan unsur haranya lebih banyak dibanding dengan lapisan bawah (subsoil). Untuk memproduksi bibit dalam skala besar diperlukan tanah lapisan atas yang cukup banyak sehingga dapat berpengaruh negatif terhadap lingkungan seperti erosi dan menurunnya kesuburan tanah. Selain itu sekarang ini sudah jarang ditemukan daerah yang lapisan topsoilnya tebal akibat erosi yang disebabkan telah banyaknya daerah yang terbuka. Kendala lain yang dihadapi adalah tanah di Bengkulu termasuk jenis Ultisol. Ultisol memiliki kelemahan sebagai media pertumbuhan semai karena tanah ini bereaksi asam, miskin hara, kapasitas tukar kation rendah dan ketersediaaan unsur bagi tanaman sangat rendah terutama untuk unsur hara nitrogen dan fosfor.

Untuk mengurangi luasnya penggunaan topsoil sebagai media pertumbuhan bibit maka perlu dicari upaya lain. Salah satu alternatif yang dapat dilakukan adalah dengan memanfaatkan lapisan subsoil. Namun lapisan subsoil memiliki beberapa kelemahan di antaranya rendahnya bahan organik dan unsur hara, sifat fisik yang jelek yaitu bertekstur berat, berat volume yang tinggi dan permeabilitas terhadap air dan udara yang rendah.

Perbaikan sifat subsoil ultisol sebagai media tumbuh bibit dapat ditempuh dengan menggunakan pembenah tanah dan menambah bahan organik. Arang kompos serbuk gergaji dan humanure diharapkankan dapat memperbaiki kelemahan subsoil ultisol. Serbuk gergaji merupakan limbah pertanian yang pemanfaatannya masih terbatas. Pada setiap usaha pengergajian kayu akan selalu kita lihat tumpukan bahkan gunungan serbuk gergaji yang semakin lama semakin tinggi. Humanure merupakan limbah kotoran manusia yang dapat menambah masalah lingkungan seperti tercemarnya air dan tanah bila tidak dikelola dengan baik. Di Bengkulu limbah kotoran manusia mengalami kenaikan setiap tahunnya. Tahun 1997 terdapat $1184 \mathrm{~m} 3$ sedangkan pada tahun 2002 terdapat 1422m3 (PDAM, 2003). Penggunaan humanure ini juga mengatasi kelangkaan pupuk anorganik yang sekarang ini melanda pengguna pupuk di Bengkulu.

Desa Pulau Beringin yang terletak di Kecamatan Pondok Kelapa Kabupaten Bengkulu Tengah yang berjarak $\pm 20 \mathrm{Km}$ dari pusat kota memiliki penduduk yang ratarata penduduknya bermata pencaharian sebagai petani tradisonal Struktur masyarakat yang kurang sejahtera dan tingkat pendapatan yang relatif rendah merupakan ciri umum dari kehidupan petani. Beberapa kendala dan faktor pembatas yang menyebabkan rendahnya pendapatan petani adalah faktor kesuburan lahan yang rendah karena sebagian lahan di Desa Pulau Beringin merupakan lahan kering, keterampilan dan modal yang dimiliki. Pendapatan di luar hasil panen padi sangat membantu meningkatkan kesejahteraan keluarga petani. Pemanfaatan serbuk gergaji dalam bentuk arang kompos, humanure dan penggunaan subsoil ultisol yang banyak terdapat di Dusun Pulau Beringin menjadi media campuran bibit tanaman kehutanan dapat dijadikan usaha tambahan dalam menambah pendapatan keluarga petani.

Paradigma pembangunan kehutanan saat ini membawa satu paradigma baru yaitu bahwa basis pembangunan kehutanan haruslah bertumpu pada masyarakat. Dengan 
demikian masyarakat ditempatkan langsung pada posisi sebagai "pelaku" pembangunan kehutanan.

Beberapa jenis tanaman kayu-kayuan yang merupakan komoditi unggulan di Provinsi Bengkulu seperti Kayu bawang dan Kayu Afrika mudah ditemukan di sekitar Desa Pulau Berigin. Keadaan ini menyebabkan penyediaan bahan tanam bukan merupakan suatu masalah. Usaha pembuatan bibit tanaman kehutanan dengan menggunakan media campuran berupa humanure, arang kompos sekam dan subsoil ultisol dapat menciptakan lapangan kerja baru yang akan menambah pendapatan keluarga petani di Desa Pulau Beringin. Selain itu kegiatan rehabilitasi hutan dan lahan akan mencapai sasaran yang diinginkan.

Tujuan kegiatan pengabdian ini adalah:

1. Memproduksi bibit tanaman hutan yang bermutu

2. Mengurangi limbah serbuk gergaji dan limbah kotoran manusia

1. Memberikan nilai tambah serbuk gergaji dan limbah kotoran manusia sehingga menjadi lebih bermanfaat

2. Mengurangi penggunaan topsoil sehingga mengurangi pengerukan tanah lapisan atas

Manfaat kegiatan pengabdian ini adalah:

1. Menambah pengetahuan para kelompok tani dalam mengelola limbah pertanian

2. Menciptakan lapangan kerja baru bagi anggota kelompok tani sehingga menambah pendapatkan para kelompok tani

3. Kelompok tani memiliki composter yang dapat dipakai untuk membuat kompos dari bahan lain selain serbuk gergaji

4. Diharapkan dapat meningkatkan kesejahteraan keluarga petani

5. Kegiatan rehabilitasi hutan dan lahan kritis dapat berhasil

\section{METODE PENGABDIAN}

Kegiatan pengabdian pada masyarakat dilakukan pada Bulan Agustus - Oktober 2014 di Dusun Pulau Beringin Kecamatan Pondok Kelapa Kabupaten Bengkulu Tengah. Sasaran dari kegiatan ini adalah anggota kelompok tani, anggota kelompok PKK dan karang taruna Desa Pulau Beringin Kecamatan Pondok Kelapa Kabupaten Bengkulu Tengah.

\section{Metode Penerapan IPTEK}

Transformasi teknologi yang efektif bagi masyarakat berpendidikan rendah adalah menggunakan metode penyuluhan, pelatihan dengan banyak membuat demonstrasi atau melakukan praktek langsung diiringi dengan pendampingan (White, 1990). Oleh karena itu dalam kegiatan penerapan IPTEKS ini digunakan metode:

a. Penyuluhan dan tatap muka: mengenai pentingnya rehabilitasi hutan dan lahan, pemanfaatan limbah lingkungan, dan mengenai cara pemasaran produk limbah 
b. Pelatihan: pengetahuan cara membuat campuran media tanam bibit yang berkualitas

c. Demonstrasi: pembuatan arang kompos serbuk gergaji dan pencampuran media tanam bibit

\section{HASIL DAN PEMBAHASAN}

Kegiatan pengabdian pada masyarakat ini dilaksanakan Bulan Agustus-Oktober 2014. Kegiatan lapangan diawali dengan sosialisasi kegiatan yaitu dengan mendatangi Kepala Dusun Pulau Beringin Tebat Monok, Bapak Padila Sandi, dan para anggota kelompok tani untuk menjelaskan tujuan diadakannya kegiatan pengabdian ini. Berdasarkan hasil interview diketahui bahwa para anggota kelompok tani di Dusun Pulau Beringin belum pernah mendapatkan informasi mengenai penanganan buah limbah.

Kegiatan pengabdian dilakukan dengan metode penyuluhan dan demonstrasi yang dilakukan di Balai Pertemuan Dusun Pulau Beringin. Kegiatan dihadiri oleh anggota Karang Taruna dan para anggota Kelompok Tani Dusun Pulau Beringin.

Secara umum pelaksanaan kegiatan pengabdian Ipteks bagi masyarakat berjalan lancar. Penyuluhan dilakukan untuk menyampaikan pengetahuan mengenai pentingnya pengelolaan limbah, pemanfaatan limbah lingkungan dan mengenai cara pemasaran produk limbah.

Ada tiga cara yang mudah untuk mengatasi masalah limbah yaitu dengan prinsip 3R yaitu:

1. Reduce (Mengurangi): sebisa mungkin lakukan minimalisasi barang atau material yang dipergunakan,

2. Reuse (Memakai kembali): sebisa mungkin pilihlah barang-barang yang bisa dipakai kembali dan hindari pemakaian barang-barang yang hanya bisa sekali digunakan (disposable),

3. Recycle (daur ulang): sebisa mungkin barang-barang yang sudah tidak terpakai didaur ulang, walaupun tidak semua barang bisa didaur ulang.

Prinsip 3R ini bisa menjadi pedoman sederhana untuk membantu kita dalam mengurangi sampah di rumah (Suryati, 2009). Pada acara penyuluhan diperkenalkan juga beberapa jenis pupuk organik lain selain pupuk tinja. Selain itu diperkenalkan juga cara pembuatan pupuk kompos yang cepat dengan memperkenalkan aktivator. Beberapa aktivator yang bisa dipakai adalah Aktivator Orgadec, Stardec, EM-4, Harmony dan FixUp dan Boisca dengan keunggulan masing-masing (Indriani, 2008).

Pemanfaatan serbuk gergaji dan pupuk tinja sebagai campuran media semai untuk bibit tanaman hutan rakyat merupakan hal yang baru bagi para anggota kelompok tani di Dusun Pulau Beringin. Selama ini limbah serbuk gergaji hanya dimanfaatkan untuk alas kandang ternak dan dalam pembuatan kolam ikan, selebihnya dibuang atau dibakar saja. Terlebih lagi dengan pemanfaatan pupuk tinja untuk campuran media tanam merupakan hal yang sangat baru bagi para anggota kelompok tani. Di Dusun Pulau Beringin limbah tinja belum merupakan masalah bagi para penduduk karena mereka masih memiliki tanah 
yang cukup luas untuk membuat lubang septic-tank yang baru bila lubang pembuangan mereka penuh. Namun hal ini pasti akan menjadi permasalahan juga karena pertumbuhan penduduk yang cukup tinggi membuat kebutuhan akan lahan juga menjadi semakin meningkat.

Pemanfaatan serbuk gergaji dalam keadaan segar tidak dianjurkan karena serbuk gergaji sangat sukar terdekomposisi dan dapat bersifat meracun bagi perakaran semai. Untuk itu perlu usaha supaya serbuk gergaji dapat dimanfaatkan dalam usaha mengurangi limbah serbuk gergaji. Salah satu usaha yang dilakukan yaitu dengan membuat arang serbuk gergaji.

Serbuk gergaji merupakan bahan organik yang sangat lambat melapuk karena mengandung komponen kimia seperti lignin, selulosa dan hemi selulosa. Serbuk gergaji juga mengandung ekstrak aktif yang dapat menghambat pertumbuhan cendawan sehinggga kesterilan media tetap terpelihara. Potensi serbuk gergaji sebagai bahan media pertumbuhan cukup besar. Pemakaian serbuk gergaji sebagai bahan organik secara langsung pada tanah dapat memberikan tambahan nitrogen yaitu dari 1,2\% menjadi $1,5 \%$ (Darusman, 1973 dalam Rosmaleni, 2004).

Serbuk gergagi mempunyai kemampuan megikat air yang tinggi sehingga tidak cepat kering. Bahan ini memiliki pori-pori makro dan mikro yang berimbang sehingga sirkulasi udara cukup baik. Campuran tanah dengan serbuk gergaji membuat media tumbuh menjadi tidak menggumpal dan kandungan airnya cukup untuk pertumbuhan juga memudahkan penetrasi akar ke dalam media. Serbuk gergaji juga mengandung 0,24 N, 0,2\% P2O5 dan 0,24\% K2O. Hasil penelitian Komarayati (1993), memperlihatkan bahwa antara media ultisol dan serbuk gergaji memperlihatkan perbedaan yang nyata terhadap persen tumbuh semai sengon yaitu pada tanah ultisol semai dapat tumbuh sebanyak $35,84 \%$ sedangkan pada serbuk gergaji hanya $24,17 \%$. Serbuk gergaji yang masih baru akan memberikan pengaruh yang kurang baik terhadap tumbuhnya semai karena tidak mobilnya nitrogen dan kemungkinan masih adanya phytotoksin.

Dalam kegiatan pengabdian ini dilakukan pembuatan arang serbuk gergaji. Arang ialah suatu bahan yang telah mengalami pembakaran dan mempunyai $\mathrm{pH}$ tertentu dimana arang dapat dimanfaatkan sebagai campuran media tanam. Secara morfologis arang memiliki pori yang efektif untuk mengikat dan menyimpan hara tanah. Oleh sebab itu aplikasi arang pada lahan-lahan terutama lmiskin hara dapat membangun dan meningkatkan kesuburan tanah karena dapat meningkatkan fungsi sirkulasi udara dan sirkulasi tanah, pH tanah, merangsang pembentukan endo dan ekto mikoriza dan menyerap kelebihan $\mathrm{CO}_{2}$ tanah sehingga dapat meningkatkan produktivitas ahan dan menyerap kelebihan $\mathrm{CO}_{2}$ tanah sehingga dapat meningkatkan produktivitas lahan dan hutan tanaman (Gusmailina, dkk., 2002).

Pemberian campuran arang serbuk gergaji dan pupuk kandang selain dapat meningkatkan bobot kering tanaman, meningkatkan $\mathrm{pH}$ tanah dan menurunkan kandungan Al tanah, kandungan unsur ini dapat meracuni tanaman. Oleh sebab itu penambahan arang 
sebagai campuran media sangat baik untuk mengantisipasi agar tidak terkena dampak keracunan (Indriani dan Muas, 1998, dalam Deselina, 2006).

Pupuk Tinja untuk kegaiatan pengabdian ini diambil dari pusat pengolahan limbah tinja milik Dinas Pertamanan dan Kebersihan berlokasi di Kelurahan Sawah Lebar Kota Bengkulu. Penggunaan pupuk tinja atau humanure dalam kegiatan pertanian merupakan kegiatan umum yang dilakukan di negara China, Vietnam dan Jepang. Khusus di Cina kegiatan ini telah dilakukan selama lebih dari 4000 tahun yang lalu, karena tinggiginya kepadatan penduduk maka volume humanure yang dihasilkan begitu besar dan jika tidak dikelola dengan baik berakibat munculnya masalah lingkungan seperti tercemarnya air dan tanah, penularan wabah penyakit (Chao, 1970, dalam Cairncross dan Duncan, 1994).

Dibandingkan dengan pupuk organik lainnya humanure mempunyai beberapa keunggulan diantaranya kandungan hara yang dihasilkan jauh lebih tinggi. Hal ini dapat dimaklumi karena manusia mempunyai menu makan yang sehat dibandingkan dengan ternak dan tanaman.

Hasil penelitian Deselina (2008) menunjukkan bahwa pemberian humanure $240 \mathrm{~g} / \mathrm{kg}$ tanah menghasilkan pertumbuhan terbaik semai jati putih pada variabel berat segar dan kering akar dan volume akar yang ditanam pada media subsoil ultisol. Deselina (2009) juga melaporkan bahwa Humanure memberikan pengaruh nyata terhadap variabel luas daun, kekokohan semai dan jumlah klorofil total daun semai mahoni daun lebar (Swietenia macrophylla King). Humanure dosis $150 \mathrm{~g} / \mathrm{kg}$ tanah memberikan pengaruh yang terbaik terhadap nilai rata-rata variabel luas daun $\left(460.55 \mathrm{~cm}^{2}\right)$ dan kekokohan semai (11.3), sedangkan pada dosis $75 \mathrm{~g} / \mathrm{kg}$ tanah, humanure memberikan pengaruh terbaik terhadap variabel jumlah klorofil total daun $\left(118,08 \mathrm{butir} / \mathrm{mm}^{2}\right)$.

Pada saat penyuluhan diberikan juga informasi mengenai pentingnya lahan pekarangan dengan tanaman agroforestri. Dengan beragroforestri penduduk memiliki tabungan masa depan. Program penanaman sengon yang dicanangkan oleh Bapak Bupati Kepahiang dapat dilakukan dengan ikut menanam tanaman pertanian yang dapat dipanen sebelum panen tanaman sengon.

Para peserta kegiatan juga memberi masukan mengenai bagaimana menanggulani limbah cair dari usaha pembuatan tahu mengingat di Dusun Pulau Beringin ini terdapat usaha pembuatan tahu milik warga Dusun Pulau Beringin. Pada musim kemarau limbah cair dari usaha pembuatan tahu ini sangat mengganggu warga karena bau menyengat yang ditimbulkan. Hal ini disebabkan aliran air pembuangan limbah cair dari usaha pembuatan tahu tersebut tidak dapat mengalir dengan baik. Dengan adanya masukan tersebut dapat dirancang mengenai tema pengabdian pada tahun anggaran mendatang. Bapak Kepala Dusun Pulau Beringin juga menginginkan adanya evaluasi dari pihak LPPM UNIB setiap tahun mengenai kegiatan pengabdian yang telah dilakukan oleh Tim Pengabdian UNIB.

Permasalahan yang dijumpai pada saat kegiatan pengabdian adalah kesulitan dalam menentukan jadwal kegiatan mengingat jarak antara penandatanganan kontrak kegiatan dan pencairan dana sangat lama sehingga menjadi salah satu kendala dalam menentukan jadwal kegiatan. Disamping itu kegiatan pengabdian yang hanya dapat dilakukan pada malam hari juga merupakan suatu kendala juga dalam menentukan jadwal pertemuan. 


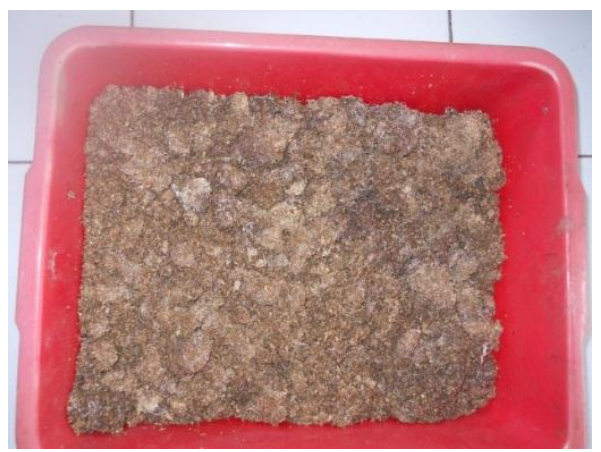

Serbuk Gergaji

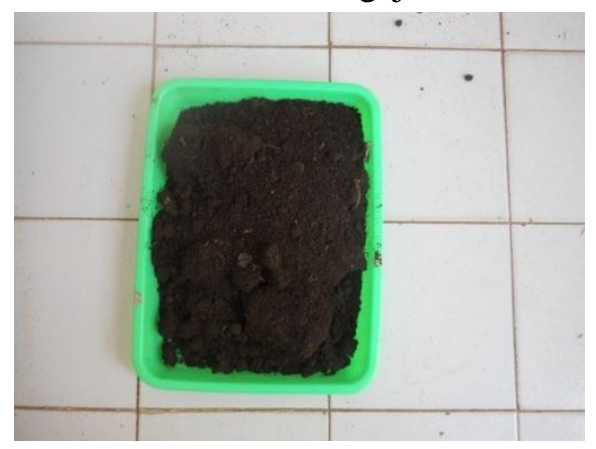

Pupuk Tinja



Arang serbuk gergaji

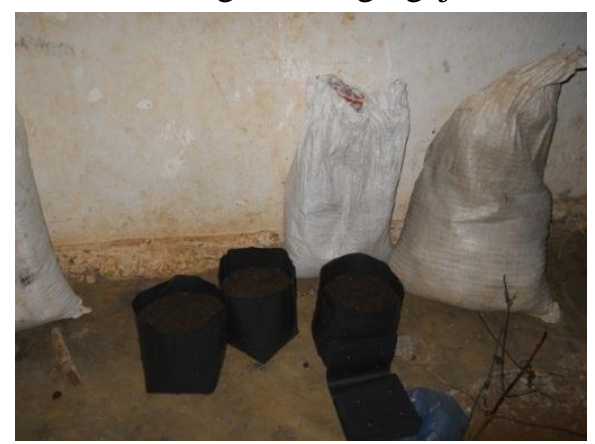

Campuran media tanam

Gambar 1. Campuran Media Tanam Bibit Hutan Tanaman Rakyat

\section{KESIMPULAN}

Pembuatan campuran media tumbuh untuk bibit hutan tanaman rakyat dari serbuk gergaji dan pupuk tinja di Dusun Pulau Beringin merupakan salah satu langkah yang tepat dalam mengolah limbah usaha pengergajian dan limbah rumah tangga. Pembuatan campuran media tumbuh dari limbah ini disamping menambah keterampilan para anggota kelompok tani dan karang taruna dalam mengelola limbah juga dapat dijadikan salah satu usaha untuk menambah pendapatan para anggota kelompok tani dan karang taruna di Dusun Pulau Beringin.

\section{DAFTAR PUSTAKA}

BP DAS Ketahun, 2007, Laporan Badan Pengelolaan Daerah Aliran Sungai Ketahun, Bengkulu Utara, Bengkulu.

Cairncrosss, S., dan M. Duncan, 1994, Pemanfaatan Air Limbah dan Ekskreta, ITB, Bandung. 
Departemen Kehutanan dan Perkebunan, 2000, Hasil Inventarisasi Lahan Kritis pada Lahan Kawasan Lahan Budidaya Pertanian, Jakarta.

Deselina, 2006, Respon Pertumbuhan Bibit Kemiri terhadap Komposisi Media Semai Berupa Campuran Arang Sekam Padi, Arang Serbuk Gergaji, Pupuk Kandang dan Subsoil Ultisol, Jurnal Agriculture, 6 (1): 107-112, Bengkulu.

Deselina, 2008, Respon Pertumbuhan Semai Jati Putih (Gmelina arborea Roxb.) terhadap Pemberian Humanure dan Arang Serbuk Gergaji, Jurnal Agroqua, Vol 6: 1: 42-49, Bengkulu.

Deselina, 2009, Tanggap Semai Mahoni (Swietenia macrophylla King.) terhadap

Pemberian Humanure pada Media Bekas Tambang Batubara dan Subsoil (Percobaan Pot). Jurnal Agriculture 14 (1), Bengkulu.

Gusmailina, G. Pari, S. Komarayati, dan T. Rostiwati, 2002, Alternatif Arang Aktif sebagai Soil Conditioning pada Tanaman, Buletin Penelitian Hasil Hutan, Vol. 19(3): 185199, Bogor.

Indriani, Y.H., 2008, Membuat Kompos Secara Kilat, Penebar Swadaya, Jakarta.

Komarayati, S., Mustaghfirin, dan K. Sofyan, 2007, Kualitas Arang Kompos Limbah Industri Kertas dengan Variasi Penambahan Arang Serbuk Gergaji. Jurnal Ilmu dan Teknologi Kayu Tropis, 5(2): 78-84.

PDAM, 2003, Laporan PDAM Bengkulu, Bengkulu.

Rosmaleni, 2004, Respon Pertumbuhan Semai Kayu Manis (Cinnamomum burmanii BL) terhadap Komposisi Media Topsoil Tandan Kososng Kelapa Sawit dan Serbuk Gergaji, Program Studi Budidaya Hutan Jurusan Kehutanan, Fakultas Pertanian Universitas Bengkulu.

Suryati, T., 2009, Bijak dan Cerdas Mengolah Sampah: Membuat Kompos dari Sampah Rumah Tangga, AgroMedia, Jakarta.

White, B., 1990, Agro-Industri, Industrialisasi Pedesaan dan Trasformasi Pedesaan. Makalah disampaikan pada rangkaian diskusi ke-100 pada Pusat Pengembangan Ilmu-ilmu Sosial (PPIS) Universitas Brawijaya, 27 Januari 1990, Malang. 